\title{
Microstructure and Properties of Mg-3Zn- 0.2Ca Alloy for Biomedical Application
}

\author{
Yang Min, Liu Debao, Zhang Runfang, Chen Minfang
}

Tianjin University of Technology, Tianjin 300384, China

\begin{abstract}
Microstructure, mechanical properties and bio-corrosion properties of $\mathrm{Mg}-3 \mathrm{Zn}-0.2 \mathrm{Ca}$ alloys were investigated for biomedical application by X-ray diffraction (XRD), optical microscopy (OM), scanning electronic microscopy (SEM), mechanical properties testing, electrochemical and immersion measurement. The XRD shows that the main second phases in the alloy are $\mathrm{Mg}-\mathrm{Zn}$ intermetallic compounds such as $\mathrm{Mg}_{7} \mathrm{Zn}_{3}, \mathrm{Mg}_{2} \mathrm{Zn}_{3}$, and $\mathrm{Mg}_{4} \mathrm{Zn}_{7}$. In comparison with the cast alloy, the average grain size of the extruded $\mathrm{Mg}-3 \mathrm{Zn}-0.2 \mathrm{Ca}$ alloy is significantly decreased by 47.6 times from $119.1 \mu \mathrm{m}$ to $2.5 \mu \mathrm{m}$ after extrusion ratio $56: 1$ deformation. The tensile yield strength ( $0.2 \% \mathrm{TYS})$, ultimate tensile strength and elongation of the extrude alloys are $205 \mathrm{MPa}, 336$ MPa and $17.85 \%$, respectively. The electrochemical and the immersion tests show that the corrosion resistance of the extruded alloy is obviously higher than that of the cast alloy due to the fine grained microstructure. The newly designed $\mathrm{Mg}-3 \mathrm{Zn}-0.2 \mathrm{Ca}$ alloy exhibits the good combination of mechanical performance and corrosion resistance for biomedical application.
\end{abstract}

Key words: $\mathrm{Mg}-\mathrm{Zn}-\mathrm{Ca}$ alloy; microstructure; mechanical property; bio-corrosion behavior

Nowadays, biodegradable implant materials have attracted increasing attention. These biodegradable materials are dissolved and absorbed in the human body after the healing process $^{[1,2]}$. Compared with traditional biomedical materials, such as stainless steel, titanium alloy and cobalt chromium alloys, biodegradable materials can avoid the risks and issues due to the removal procedure. In contrast, the existence of permanent implants in the human body can cause allergic reactions and sensitization ${ }^{[3]}$. Magnesium and its alloys for bo medical implant have attracted more people to investigate due to the combination of good mechanical properties and bo compatibilities ${ }^{[4,5]}$. Furthermore, $\mathrm{Mg}$ is also a fundamental element to the human body which is involved in many metabolic functions as it naturally exists in bone tissue ${ }^{[6]}$. And $\mathrm{Mg}$ can directly influence bone-resorbing cells and be an important factor for bone metabolism ${ }^{[5-7]}$. Many clinical cases as well as in vivo and in vitro assessments have suggested that Mg-base implants exhibit good biocompatibility ${ }^{[7-9]}$. The major drawback of magnesium alloys serving as implant materials at present is their poor corrosion resistance in physiological environment and relevant mechanical properties such as ductility and toughness. The addition of alloy elements is an effective means to improve the mechanical properties and corrosion resistance. For example, Zinc is a crucial element for the human body and it is necessary for many biological functions ${ }^{[6]}$. Furthermore, $\mathrm{Zn}$ alloying can improve the anti-corrosion properties and mechanical properties of magnesium alloys. $\mathrm{Ca}$ is also one of the alloying elements that can modify the microstructure and properties of magnesium alloys. Furthermore, $\mathrm{Ca}$ is a major component of the human bone and can accelerate bone. Therefore, $\mathrm{Mg}-\mathrm{Zn}-\mathrm{Ca}$ alloys application for degradable bone internal fixation has been studied in recent years. However, excessive calcium in $\mathrm{Mg}-\mathrm{Zn}-\mathrm{Ca}$ alloy led to the formation of $\mathrm{Mg}_{2} \mathrm{Ca}$ and $\mathrm{Ca}_{2} \mathrm{Mg}_{6} \mathrm{Zn}_{3}$, which are brittle phases that decrease ductility and strength. Therefore, in this paper, the amount of $0.2 \mathrm{wt} \%$ calcium was suggested to fabricate the $\mathrm{Mg}-3 \mathrm{Zn}-0.2 \mathrm{Ca}$ alloy, and prevent excess brittle phases in matrix. Low strain rate was applied in extrusion process to avoid hot tear. Microstructure, mechanical properties and bio-corrosion

Received date: January 05, 2017

Foundation item: National Natural Sciences Foundation of China (51271131); Key Projects Supported by Tianjin Science and Technology (15ZCZDSY00920)

Corresponding author: Liu Debao, Ph. D., Professor, School of Materials Science and Engineering, Tianjin University of Technology, Tianjin 300384, P. R. China, Tel: 0086-22-60214008, E-mail: debaoliu@126.com

Copyright (C) 2018, Northwest Institute for Nonferrous Metal Research. Published by Elsevier BV. All rights reserved. 
properties of as-extruded $\mathrm{Mg}-3 \mathrm{Zn}-0.2 \mathrm{Ca}$ alloys were investigated for biomedical application, with the as-cast of this alloy as control.

\section{Experiment}

Mg-3Zn-0.2Ca alloy was prepared by $\mathrm{Mg}-30 \mathrm{wt} \% \mathrm{Ca}$ master alloy, purity $99.99 \mathrm{wt} \% \mathrm{Mg}$ and $99.99 \mathrm{wt} \% \mathrm{Zn}$ using a vacuum smelting method protected by $99.999 \%$ Argon. The melting temperature was $720{ }^{\circ} \mathrm{C}$. Then the melt was cast into a copper mold. After $400{ }^{\circ} \mathrm{C}$ homogenization for $12 \mathrm{~h}$, the as-cast alloy was extruded at $300 \mathrm{C}$ with an extrusion ratio of 56 and extrusion rate of $0.1 \mathrm{~mm} / \mathrm{s}$.

Samples for XRD and microstructure observation were cut from the extruded bars and ingots, respectively, ground by $\mathrm{SiC}$ papers up to 3000 grit, and then polished by polishing solution $\left(\mathrm{HNO}_{3}, \mathrm{CH}_{3} \mathrm{OH}\right)$. The samples were etched by chemical etching (2.75 g picric aid, $45 \mathrm{~mL}$ ethanol, $2.5 \mathrm{~mL} 99.5 \%$ acetic acid and $5.0 \mathrm{~mL}$ deionized water). XRD (Rigaku D/max/ 2500PC) test was conducted on $\mathrm{Cu} \mathrm{K \alpha}$ radiation, operating at a voltage of $40 \mathrm{kV}$ and a current of $40 \mathrm{~mA}$. Microstructure observation was conducted on optical microscope (OM) and scanning electronic microscope (SEM).

Tensile samples were cut from the extruded bar. The tensile sample with a gauge length of $20 \mathrm{~mm}$ and a diameter of $4 \mathrm{~mm}$ is shown in Fig.1. Tensile strength was tested on an electronic universal testing machine with the tensile rate $20 \mathrm{~mm} / \mathrm{min}$. At least three samples were tested for each condition.

Circular specimens with a diameter of $8 \mathrm{~mm}$ and a thickness of $3 \mathrm{~mm}$ for the electrochemical test were covered by One Component RTV Silicone with an exposed area of 0.5 $\mathrm{cm}^{2}$. The working surface was ground with $\mathrm{SiC}$ papers up to 3000 grit. Electrochemical test was carried out by electrochemical workstation with three-electrode configuration in simulated body fluid. A saturated calomel electrode (SCE) and a graphite electrode were used as the reference and counter electrode, respectively. The working electrode was the magnesium alloy sample. The open circuit potential (OCP), the polarization curves and the electrochemical impedance spectroscopy (EIS) were carried out using electrochemical tests. Polarization curves were measured at a scan rate of $0.01 \mathrm{~V} / \mathrm{min}$ and EIS experiments were performed in the frequency range from $100 \mathrm{kHz}$ to 1 $\mathrm{mHz}$, with a sinusoidal signal perturbation of $10 \mathrm{mV}$.

Immersion samples were immersed in $40 \mathrm{~mL}$ SBF for 3, 7

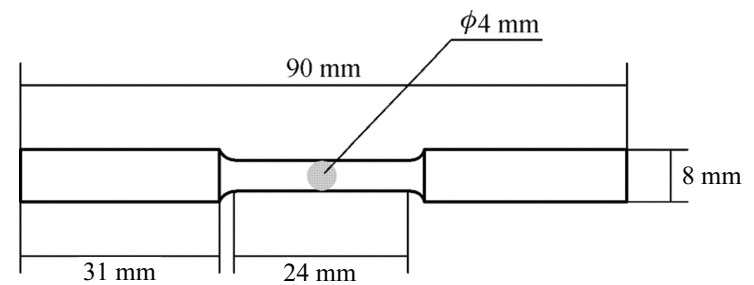

Fig.1 Diagrammatic sketch of the tensile sample and $15 \mathrm{~d}$ at $37^{\circ} \mathrm{C}$. Changes in the chemical composition of the SBF caused by corrosion of the alloys were monitored by the volume of $\mathrm{H}_{2}$ evolved from the alloys.

\section{Results and Discussion}

\subsection{XRD and microstructure analysis}

The XRD results of the as-cast and extruded Mg-3Zn-0.2Ca alloy are presented in Fig.2, which shows that the main constituent phases of the prepared $\mathrm{Mg}-3 \mathrm{Zn}-0.2 \mathrm{Ca}$ alloy are $\alpha-\mathrm{Mg}$ and some second phases such as $\mathrm{Mg}_{7} \mathrm{Zn}_{3}$, $\mathrm{Mg}_{2} \mathrm{Zn}_{3}$ and $\mathrm{Mg}_{4} \mathrm{Zn}_{7}$. However, no distinct second phase was detected in the extruded sample. The reason for this result is that during extrusion, some second phases such as $\mathrm{Mg}_{7} \mathrm{Zn}_{3}$, $\mathrm{Mg}_{2} \mathrm{Zn}_{3}$ phase were broken into smaller ones, which is difficult to be detected by XRD.

In comparison with the cast alloy, the relative intensities of peaks related to $\mathrm{Mg}$ matrix (Fig.2b) have changed due to the grain orientation after extrusion. As cast state, the three strongest diffraction peaks are (0002), (1011) and (10 $\overline{1} 2)$ plane. As extruded state, the three strongest diffraction peaks are changed to $(10 \overline{1} 0),(10 \overline{1} 1)$ and $(11 \overline{2} 0)$ plane. $(10 \overline{1} 1)$ and $(10 \overline{1} 0)$ plane are corresponding to cone and cylinder slip system, indicating that cone and cylinder slip are the main slip system during high temperature deformation. Fig.3 presents optical micrograph and SEM image for as-cast $\mathrm{Mg}-3 \mathrm{Zn}-0.2 \mathrm{Ca}$ alloy. It can be seen that the average grain size of the primary $\alpha$-Mg phase is $120 \sim 130 \mu \mathrm{m}$ and some spherical second phases with average diameter of $2 \sim 3 \mu \mathrm{m}$ are distributed mainly within grains. It also can be seen that in addition to some spherical
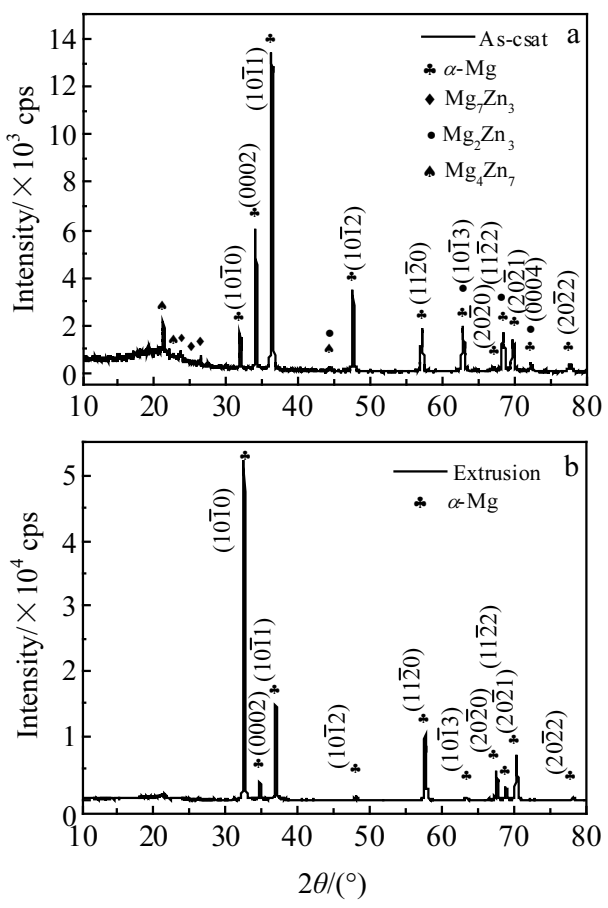

Fig.2 XRD patterns for as-cast $\mathrm{Mg}-3 \mathrm{Zn}-0.2 \mathrm{Ca}$ alloy (a) and extruded Mg-3Zn-0.2Ca alloy (b) 


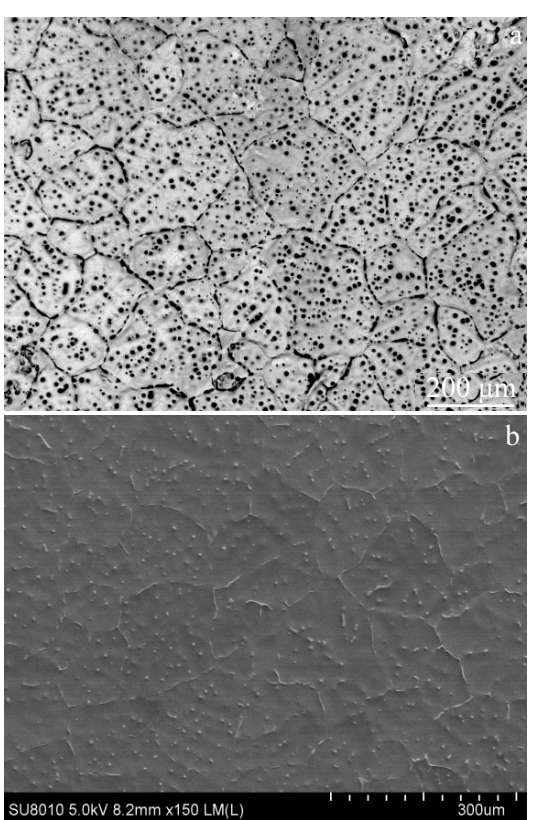

Fig.3 Optical micrograph (a) and SEM image(b) for as-cast Mg-3Zn-0.2Ca alloy

secondary phases, some secondary phases are distributed along the grain boundaries of $\alpha-\mathrm{Mg}$ matrix as shown in Fig. $3 \mathrm{~b}$. Fig.4a shows the optical micrographs of the cross section of extruded alloy. The average grain size of the extruded alloy is $2.5 \mu \mathrm{m}$ and the secondary phases are hardly observed in the OM images, indicating that the microstructure is significantly refined, however, a few precipitate phases can be found in the grains and at the grain boundaries in the SEM image as shown in Fig.4b. After hot extrusion, both the matrix and the precipitates are refined. The refined precipitates distribute in the recrystallized grains and their boundaries retard the growth of recrystallization grains. Fig. $4 \mathrm{c}$ and $4 \mathrm{~d}$ are the optical micrographs of extruded $\mathrm{Mg}-3 \mathrm{Zn}-0.2 \mathrm{Ca}$ alloy along the extrusion direction. It can be seen that the as-extruded alloy exhibits a typical fiber texture. Note that a small amount of unrecrystallized regions (Fig.4c, white arrows) could be observed in the extruded alloy, and the unrecrystallized grains are transmutative due to the plastic deformation. It can be clearly seen that the secondary phase is distributed along the extrusion direction (Fig.4d). Undoubtedly, the microstructure of the extruded alloy is significantly different from the as-cast alloy resulting in the tremendous difference of properties.

\subsection{Mechanical analysis}

Fig.5 presents the tensile stress-strain curve of the extruded $\mathrm{Mg}-3 \mathrm{Zn}-0.2 \mathrm{Ca}$ alloy. The tensile yield strength ( $0.2 \% \mathrm{TYS})$, ultimate tensile strength (UTS) and elongation to failure of the alloy are 205, $336 \mathrm{MPa}$ and $17.85 \%$, respectively. In this work, the addition of $\mathrm{Zn}$ and element can effectively refine the grain size and improve the strength of $\mathrm{Mg}$ alloy. It is supposed that the addition of $\mathrm{Ca}$ to magnesium alloy can affect the grain refinement during solidification process. According to the growth restriction factor GRF mechanism ${ }^{[10]}$, the larger the value of GRF, the higher the refinement efficiency will be. The value of GRF of $\mathrm{Ca}$ is up to 11.91, therefore, Ca element possess higher refinement efficiency. The refinement of the grain size in the extruded alloys is most likely a consequence of the influence of $\mathrm{Ca}$ element on dynamical recrystallization. Relevant study confirmed that the addition of low content of calcium strongly weakens the texture and refines the grain sizes of the magnesium alloys. The weakening of the textures and fine grains is related to the particle stimulated nucleation of recrystallization and the appearance of desolventizing phase which restricts the dynamic recrystallized grains growth ${ }^{[11]}$.

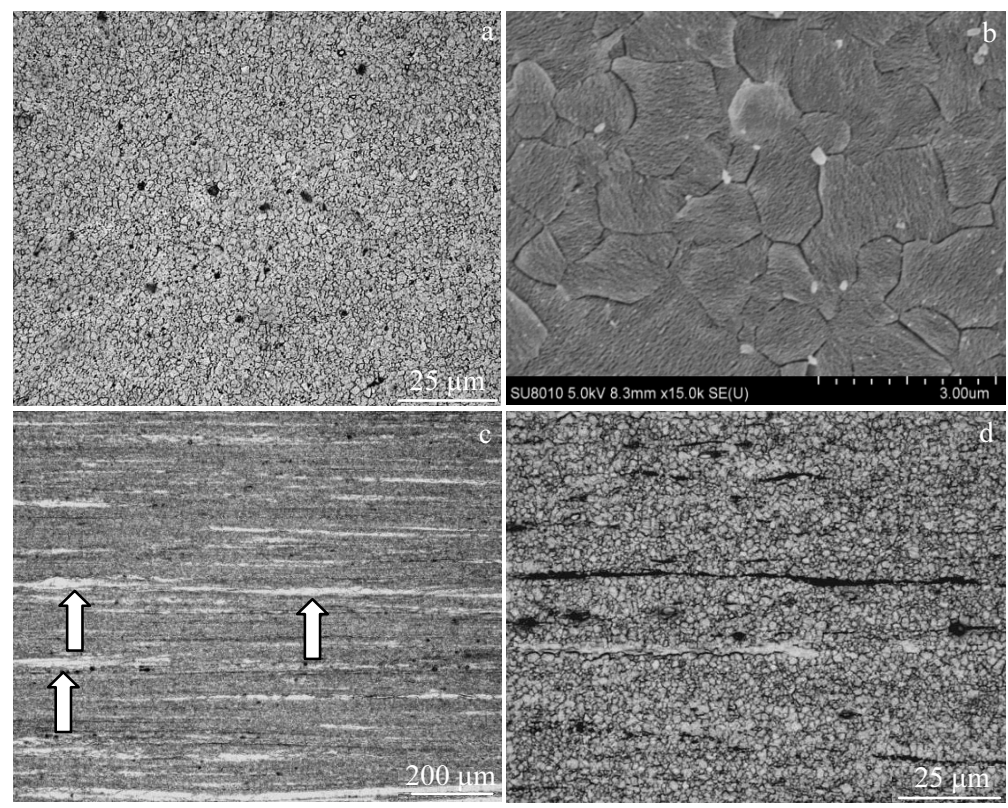

Fig.4 Optical micrographs (a, c, d) and SEM image (b) for extruded Mg-3Zn-0.2Ca alloy 
Moreover, the extrusion ratio up to 56 and extrusion speed is very low $(0.1 \mathrm{~mm} / \mathrm{s})$, which are beneficial to dynamic recrystallization. The fine grain size and weakening of the textures result in good combined mechanical properties.

Fig. 6 exhibits the morphology of the fracture of the tensile extruded $\mathrm{Mg}-3 \mathrm{Zn}-0.2 \mathrm{Ca}$ alloy. A few cleavage surfaces and tearing ridges (white arrows in Fig.6), which were taken as typical brittle fracture features, could be seen on the fracture surfaces. However, there are lots of dimples on the fracture surface of the extruded $\mathrm{Mg}-3 \mathrm{Zn}-0.2 \mathrm{Ca}$ alloy, indicating that the main fracture of the extruded alloy is ductile fracture.

\subsection{Electrochemical results and discussion}

The polarization curves from electrochemical tests are shown in Fig.7a. The corrosion potential of the as-cast and extruded alloy is -1.793 and $-1.743 \mathrm{~V}$, respectively. The corrosion potential indicates that electrochemical reactions take place in the electrode/solution interface. This suggests that the extruded alloy exhibits lower susceptibility to electrochemical reaction. It also can be seen that the anodic curve of the extruded alloy shows evident passivation process when compared with the as-cast alloy, indicating that surface film on the extruded alloy exhibits evident passivation effect. Fig. $7 \mathrm{~b}$ presents the EIS curves of the as-cast and extruded $\mathrm{Mg}-3 \mathrm{Zn}-0.2 \mathrm{Ca}$ alloy. The capacitive loop in the middle frequency is attributed to the mass transportation process ${ }^{[12]}$. The high frequency semicircle has been assigned to charge transfer and film effects, the middle frequency semicircle to relaxation of mass transport through the corrosion product

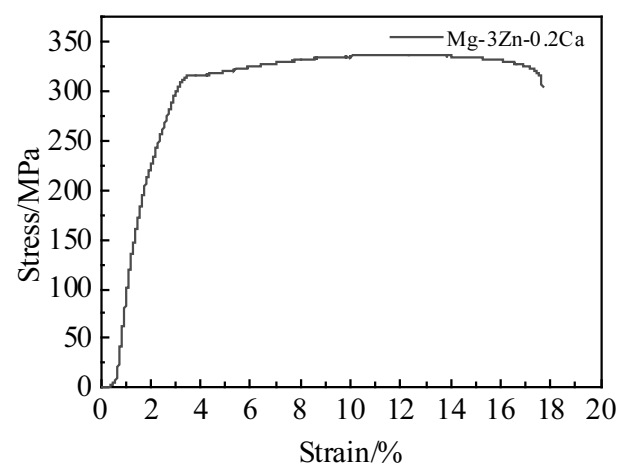

Fig.5 Tensile stress-strain curve for extruded $\mathrm{Mg}-3 \mathrm{Zn}-0.2 \mathrm{Ca}$ alloy

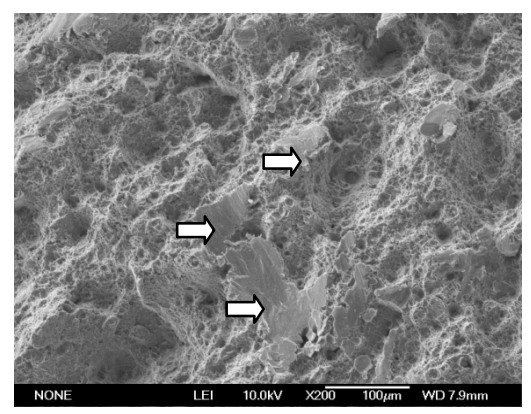

Fig.6 Fractography for extruded $\mathrm{Mg}-3 \mathrm{Zn}-0.2 \mathrm{Ca}$ alloy
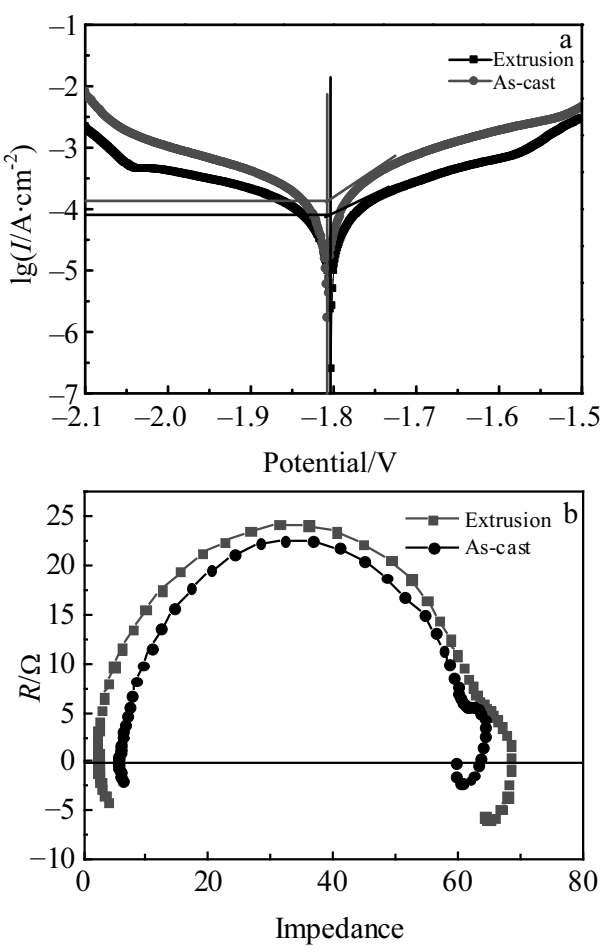

Fig.7 Polarization curves (a) and EIS (b) of the as-cast and extruded $\mathrm{Mg}-3.0 \mathrm{Zn}-0.2 \mathrm{Ca}$ alloy

layer and the low frequency inductive loop has been connected to relaxation of adsorbed species ${ }^{[13-15]}$. Compared with the as-cast alloy, the diameter of both capacitive loops is lager. The diameter of the capacitive semicircle of a Nyquist plot is related to the corrosion rate and an increase in the diameter represents a decrease in corrosion rate. Furthermore, the inductive loop of the as-cast alloy becomes almost invisible indicating an increasing passivation area. These features of EIS curves indicate the corrosion resistance of extruded alloy is better than as-cast one.

Fig. 8 presents open circuit potentials (OCP) of the as-cast and extruded $\mathrm{Mg}-3 \mathrm{Zn}-0.2 \mathrm{Ca}$ alloy in the SBF. For the extruded alloy, the rapid increase in corrosion potential in the initial stage of the test sample within about $500 \mathrm{~min}$, and then corrosion potential gradually reaches the maximum about $-1.52 \mathrm{~V}$ after approximate $1500 \mathrm{~min}$. The variation of the OCP value from beginning to $1500 \mathrm{~min}$ can be attributed to the formation of passive film. After $1500 \mathrm{~min}$, the potential fluctuation can be observed, which imply the occurrence of pitting corrosion and the self-limiting effect of pitting corrosion. As for as-cast alloy, the OCP value still gradually increases from beginning to 2200 min and is still lower than extruded alloy, and then potential fluctuation also can be observe, which imply the generation time of pitting corrosion is later than extruded alloy.

Fig.9 presents the amount of $\mathrm{H}_{2}$ evolved from the as-cast and extruded $\mathrm{Mg}-3 \mathrm{Zn}-0.2 \mathrm{Ca}$ alloy during immersion for $25 \mathrm{~h}$ in the SBF. The amount of $\mathrm{H}_{2}$ evolved from the as-cast alloy and the extruded alloy are increased with the evolution of the 


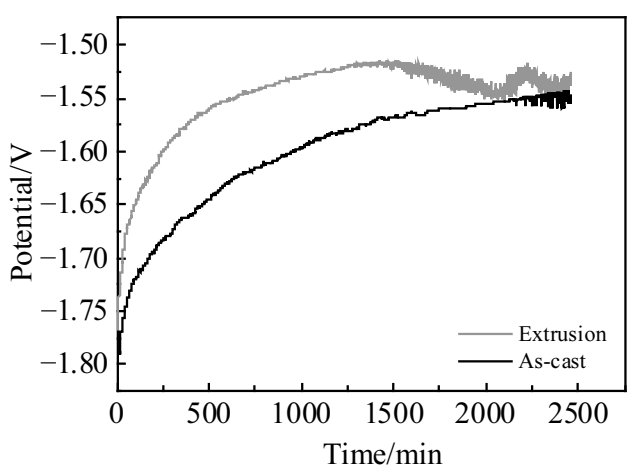

Fig.8 Open-circuit potential vs immersion time of $\mathrm{Mg}-3.0 \mathrm{Zn}-0.2 \mathrm{Ca}$ alloys in SBF solution

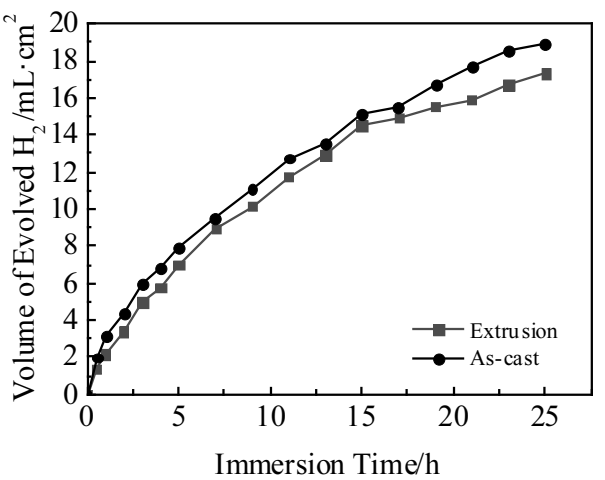

Fig.9 Volume of $\mathrm{H}_{2}$ evolved from the $\mathrm{Mg}-3.0 \mathrm{Zn}-0.2 \mathrm{Ca}$ alloys in SBF solution

time, and the volume of $\mathrm{H}_{2}$ of the as-cast alloy is still larger than that of the extruded alloy. The total volume of evolved $\mathrm{H}_{2}$ of the as-extruded alloy and the as-cast alloy after immersed for $25 \mathrm{~h}$ in the SBF are 8.7 and $9.5 \mathrm{~mL}$, respectively. When magnesium alloys are corroded in aqueous environment, the corresponding anodic and cathode reactions are given in Eqs. (3) and (4) respectively ${ }^{[15]}$.

Anodic reaction: $\mathrm{Mg} \rightarrow \mathrm{Mg}^{2+}+2 \mathrm{e}^{-}$

Cathode reaction: $2 \mathrm{H}_{2} \mathrm{O}+2 \mathrm{e}^{-} \rightarrow \mathrm{H}_{2}(\mathrm{~g})+2 \mathrm{OH}^{-}$

In the SBF solution, the characteristics of the initial stage corrosion for $\mathrm{Mg}$ are slow hydrogen evolution and uniform formation of solid corrosion products on the surface. With increasing immersion time, it is thermodynamically stable to dissolve $\mathrm{Mg}$ as a form of $\mathrm{Mg}^{2+}$ and increase the $\mathrm{pH}$ value of the solution adjacent to the surface. Therefore the variation trend is in consistent with the electrochemical measurement results.

Fig.10 shows the surface corrosion morphologies of as-cast alloy and extruded alloy with immersion in SBF for $72 \mathrm{~h}$. It should be noted that the corrosion layer on the surface of as extruded alloy still maintains integrity after $72 \mathrm{~h}$; however the corrosion layer on the as-cast alloy becomes loose, which imply more stable protective film can be produced on the

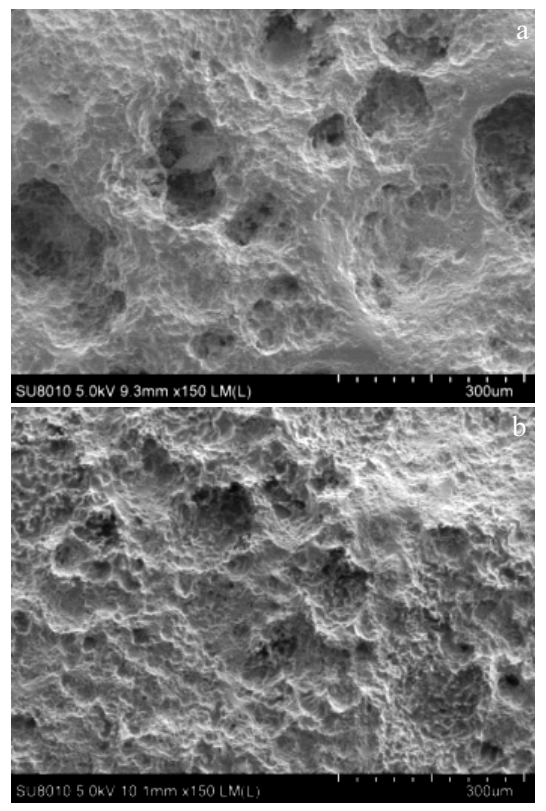

Fig.10 Surface corrosion morphologies of $\mathrm{Mg}-3.0 \mathrm{Zn}-0.2 \mathrm{Ca}$ alloys in SBF for $72 \mathrm{~h}$ : (a) as-cast and (b) as extruded

extruded alloy; thereby the corrosion resistance can be improved.

The improvement of corrosion resistance of extruded alloy can be attributed to the grain refinement. With the decreasing of grain size, there will be higher density of nucleation sites for producing surface film, which leads to rapider formation of passive layers through diffusion and more active electrons near boundaries, thus leading to higher fraction of passive layers ${ }^{[16]}$. Whereas, in the larger film pore in the surface of coarse-grained as-cast alloy, the loose $\mathrm{Mg}(\mathrm{OH})_{2}$ corrosion product cannot effectively protect the substrate alloy. Moreover, a fine-grained microstructure most likely provides a means for relieving tensile or compression stresses in the surface film by producing porosity through vacancy supply via grain boundaries, thus reducing the tendency of film cracking. Based on the above analysis, the more corrosion resistance of fine grain (as extruded alloy) can be related to lower corrosion rate than coarse grain (as-cast alloy).

\section{Conclusions}

1) In comparison with the cast alloy, the average grain size of the extruded $\mathrm{Mg}-3 \mathrm{Zn}-0.2 \mathrm{Ca}$ alloy is significantly decreased from $119.1 \mu \mathrm{m}$ to $2.5 \mu \mathrm{m}$ after extrusion ratio 56:1. The result of XRD indicates that cone and cylinder slip are the main slip system during high temperature deformation.

2) The extruded $\mathrm{Mg}-3 \mathrm{Zn}-0.2 \mathrm{Ca}$ alloys exhibits good combined mechanical properties. The fine grain size $(2.5 \mu \mathrm{m})$ and weakening of the textures result in good combined mechanical properties.

3) The corrosion resistance of as extruded alloy is higher than that of as-cast alloy due to the grain size refinement. The 
improvement in the corrosion resistance is attributed to that refine grain can produce more uniform and denser film on the surface of magnesium alloysample.

\section{References}

1 Zheng Y F, Gu X N, Witte F. Materials Science \& Engineering R: Reports[J], 2014, 77: 1

2 Gu X, Xie X, Li N et al. Acta Biomaterialia[J], 2012, 8: 2360

3 Shi Y, Qi M, Chen Y et al. Materials Letters[J], 2011, 65: 2201

4 Staiger M P, Pietak A M, Huadmai J et al. Biomaterials[J], 2006, 27(9): 1728

5 Chen Yongjun, Xu Zhigang. Acta Biomaterialia[J], 2014, 10: 4561

6 Sun Y, Zhang B, Wang Y. Materials and Design[J], 2012, 34: 58

7 Song G L, Song S Z. Advanced Engineering Materials[J], 2007, 9(4): 298
8 Hu G S, Zhang D F, Tang T et al. Rare Metal Materials and Engineering[J], 2016, 45(5): 1111(in Chinese)

9 Witte F, Fischer J, Nellesen J et al. Biomaterials[J], 2006, 27: 1013

10 Lee S, Lee S H, Kim D H. Metall Mater Trans A[J], 1998, 29: 1221

11 Zhang Baoping, Wang Yin, Geng Lin et al. Materials Science and Engineering $A[\mathrm{~J}], 2012,539: 56$

12 Baril G, Pebere N. Corrosion Science [J], 2001, 43(3): 471

13 Pébère N, Riera C, Dabosi F. Electrochimica Acta[J], 1990, 35: 555

14 Baril G, Pébère N. Corrosion Science[J], 2001, 43: 471

15 Baril G, Banc C, Pébère N. Journal of the Electrochemical Society[J], 2001, 148(12): B489

16 Liu Yichi, Liu Debao, You Chen et al. Frontiers of Materials Science[J], 2015, 9(3): 247

\title{
生物医用 Mg-3Zn-0.2Ca 合金显微组织与性能研究
}

\author{
杨 敏，刘德宝，张润芳，陈民芳 \\ (天津理工大学, 天津 300384)
}

\begin{abstract}
摘 要: 针对生物医用 $\mathrm{Mg}-3 \mathrm{Zn}-0.2 \mathrm{Ca}$ 的显微组织、力学性能以及生物腐蚀行为, 采用 $\mathrm{X}$ 射线衍射 $(\mathrm{XRD})$ 、光学显微镜 $(\mathrm{OM})$ 、扫描电镜 $(\mathrm{SEM}) 、$ 拉伸实验机、电化学以及浸泡测试方法进行了研究。XRD 结果表明 Mg-3Zn-0.2Ca 合金中的第二相主要为 $\mathrm{Mg}_{7} \mathrm{Zn}_{3}, \mathrm{Mg}_{2} \mathrm{Zn}_{3}, \mathrm{Mg}_{4} \mathrm{Zn}_{7}$ 等金属间化合物相。相比于铸态, 经过 56:1 挤压比变形后的 $\mathrm{Mg}-3 \mathrm{Zn}-0.2 \mathrm{Ca}$ 合金晶粒明显细化, 平均晶粒尺寸从 $119.1 \mu \mathrm{m}$ 降到 $2.5 \mu \mathrm{m}$, 降低了 47.6 倍。挤压态 $\mathrm{Mg}-3 \mathrm{Zn}-0.2 \mathrm{Ca}$ 合金的屈服强度 $(0.2 \% \mathrm{TYS})$ 、抗拉强度以及延伸率分别为 $205,336 \mathrm{MPa}$ 和 $17.85 \%$, 电化学以及 浸泡测试表明挤压态合金的耐蚀性明显优于铸态 $\mathrm{Mg}-3 \mathrm{Zn}-0.2 \mathrm{Ca}$ 合金, 其主要归因于晶粒细化。新设计的生物医用 $\mathrm{Mg}-3 \mathrm{Zn}-0.2 \mathrm{Ca}$ 合金呈 现出了良好的综合力学性能以及生物耐蚀性。
\end{abstract}

关键词: Mg-Zn-Ca 合金; 显微组织; 力学性能; 生物腐蚀行为

作者简介: 杨 敏, 女, 1989 年生, 硕士生, 天津理工大学材料科学与工程学院, 天津 300384, 电话: 022-60216916, E-mail: 469113074@qq.com 